Revista Brasileira

de Estudos de

Cinema

e Audiovisual

\title{
Notas sobre o documentário brasileiro moderno
}

Laécio Ricardo de Aquino Rodrigues ${ }^{1}$

${ }_{1}^{1}$ Doutor em Multimeios pelo Instituto de Artes da Unicamp e professor do Departamento de Comunicação Social da Universidade Federal de Pernambuco, vinculado ao Bacharelado de Cinema e Audiovisual. e-mail: laecioricardo@gmail.com 


\section{Resumo}

Após breve releitura sobre a emergência do documentário moderno, tradição marcada pelo advento dos equipamentos de registro síncrono (tomada direta), pela adoção de uma nova ética a orientar a relação cineasta/personagens e pela prática da reflexividade, o artigo reavalia o processo de modernização do documentário brasileiro. Em geral, apesar de ter sido lançado apenas em 1984, Cabra marcado para morrer é apontado como a obra que melhor equacionaria tais procedimentos, convertendo-se no grande marco desta transição. Nosso objetivo, porém, é destacar o pioneirismo de três outros títulos neste ciclo de mudanças, um pioneirismo quase sempre eclipsado pela fulgurância de Cabra Marcado.

Palavras-chave: documentário brasileiro; cinema direto; revisão crítica.

\section{Abstract}

After a brief review about the emerging modern documentary in the West, a tradition marked by the development of synchronized sound, the adoption of a new ethics to orientate the relationship between filmmaker and the otherness, and the practice of reflexivity, this paper investigates the modernization of Brazilian documentary. In general, despite having been released only in 1984, Cabra marcado para morrer is identified as the work that best assimilates such procedures, thus becoming the main reference in this transition. However, our goal is to highlight the of three other pioneer titles, in this cycle of changes. A primacy not always recognized due to the brilliance of Cabra marcado.

Keywords: Brazilian documentary; direct cinema; critical review. 
O desenvolvimento das tecnologias portáteis de registro síncrono do som e da imagem (tomada direta), em fins dos anos de 1950, juntamente com o florescimento de uma nova ética na relação cineasta/personagem no documentário (ética que limitava a autoridade do realizador e a pretensão totalizante de muitos filmes), promoveram uma ruptura neste domínio audiovisual: a chamada transição do modelo clássico para o moderno (BARNOUW, 1993; GAUTHIER, 2011). Neste contexto, a estilística clássica, caracterizada pela presença de uma voz over didática e pela afasia dos sujeitos abordados ${ }^{2}$, cede espaço a um fascínio crescente pela fala e presença do outro em cena, bem como pela adoção de procedimentos narrativos que valorizam a complexidade do mundo, em vez de reduzi-la a esquemas mecânicos (relações de causa e efeito).

Em outros termos, esta transição sinaliza a ascensão de uma prática cinematográfica marcada por um menor controle do realizador e por uma maior confiança na desenvoltura dos sujeitos em cena. Isto não implica dizer que o modelo clássico, com sua gramática peculiar, fora sepultado. Mas os ventos do período anunciavam um revigoramento do campo documental, alicerçado pelas inovações técnicas ${ }^{3}$ e pela adoção de novas premissas éticas e estéticas. Embora

\footnotetext{
${ }^{2}$ Emprego aqui o termo "documentário clássico" para me referir, prioritariamente, às produções que adotam uma estilística marcada pelo controle excessivo do realizador (monopólio da voz), ilustrado pelo uso de uma voz over didática e, quase sempre, pelo mutismo da alteridade. Tais obras também se caracterizam pelo enfoque totalizador, que privilegia leituras unívocas. A escola inglesa, capitaneada por John Grierson, desponta como o avatar deste modelo, embora outras cinematografias se encaixem neste perfil (o cinema do esforço de guerra; os cinemas educativos). No entanto, reconheço que, sob o rótulo "documentário clássico", figura uma diversidade de propostas e realizadores que não se encaixam nesta descrição. Cito os exemplos de Vertov, de Joris Ivens, de Resnais (produção documental), de Georges Franju e do Free Cinema, dentre outros.

${ }^{3} \mathrm{~A}$ tecnologia que culminou no florescimento dos equipamentos portáteis e síncronos, cabe destacar, não desponta subitamente, sem antecedentes. É importante mencionar aqui as pesquisas com som alavancadas pela escola britânica, em cujo grupo se destacava o brasileiro Alberto Cavalcanti, e as conquistas alimentadas pelo esforço de guerra (o desenvolvimento de películas mais sensíveis e de alguns gravadores portáteis), por exemplo. Todavia, apesar destes avanços, é somente no contexto de transição dos anos de 1950/1960 que o aparato técnico possibilita o pleno êxito da tomada direta.
} 
o presente ensaio privilegie o contexto brasileiro, e destaque a singularidade de três títulos nem sempre mensurados em seu caráter inovador, acredito ser interessante recapitular aqui algumas vertentes exemplares do documentário moderno. Em certa medida, creio que as questões salientadas por uma ou outra escola irão reverberar na prática brasileira, como ilustrará posteriormente a leitura da tríade fílmica mencionada.

Nos EUA, por exemplo, este período foi marcado pela ascensão do cinema direto, cujo preceito maior era a exigência de uma voz silente por parte do cineasta e o uso de uma câmera em recuo, no intuito de tentar flagrar a espontaneidade do mundo em seu transcorrer (NICHOLS, 2005; MARCORELLES, 1973). Orientados pelo desejo de acompanhar e registrar, continuamente, o fluxo da vida e a movimentação dos personagens em suas atividades diárias, os diretores desta escola procuravam vincular-se intimamente ao cotidiano dos sujeitos por eles documentados. A premissa é observar sem intervir/interagir diretamente, posição que ambiciona uma questionável invisibilidade na tomada e cujo ideal idílico, segundo Marcorelles (1973), seria o apagamento de toda e qualquer mediação (a possibilidade de um acesso imediato ao mundo, o desabrochar de um olhar sem suporte).

Em contrapartida, na França, despontaria simultaneamente o cinema-verdade, cujo expoente é o antropólogo Jean Rouch; nesta vertente, em vez da discrição pretendida pelos colegas americanos, vislumbramos um envolvimento e interação maior do cineasta com o universo abordado no filme. Em síntese, é sua presença agenciadora que estimula derivas narrativas e instiga a fabulação dos personagens, forjando níveis de indiscernibilidade para o espectador e expondo a fragilidade da dicotomia ficção/documentário (DELEUZE, 2009). Por conseguinte, em vez de registros orientados por um ideal de "invisibilidade" da equipe, testemunhamos nos filmes desta tradição unicamente a "verdade de um encontro", com suas hesitações, ambiguidades e a reinvenção de subjetividades diante da câmera. Amparados em texto consagrado de Comolli (2010), poderíamos dizer que tais obras valorizam a inevitável "perversão" ou vocação do 
direto 4 .

Com regularidade, a historiografia do cinema insiste em opor tais tradições, estabelecendo polaridades. Mas, se as diferenças entre ambas são evidentes, também o são as afinidades. E creio que uma melhor compreensão do direto só pode ser alcançada se ressaltadas tais convergências. Assim, apesar das divergências, as duas escolas apontadas demonstram forte interesse pela fala/gestualidade do "outro" na tomada (o direto parece colocar a experiência da audição, durante a fruição fílmica, em condições de igualdade com a visão) e pelo "frenesi das ruas", recuperando uma espécie de frescor que se encontrava ausente do documentário clássico. Escasso uso de iluminação artificial, câmera e enquadramento trepidantes, foco instável e som impuro (marcado pela presença de ruídos externos) caracterizam a estilística modesta destas produções, estilística que, no limite, será aclamada sob a denominação suspeita de "estética do real" (DA-RIN, 2004), como se tais procedimentos fossem fiadores de uma tomada com "maior aderência ao mundo". Neste contexto de ascensão do direto, e de forma majoritária no cinema-verdade, a reflexividade desponta como prática exemplar: a palavra de ordem é abdicar de qualquer pretensão especular, evidenciando para o público as decisões que presidiram a realização do filme - em outras palavras, o documentário exibe em seu corte final as pegadas de sua feitura.

Tais tendências, com um pouco de atraso, aportam no Brasil em meados da década de 1960. Como sugere Bernardet (2003), ao inventariar parte significativa da produção documental que desponta entre nós após 1963, o contexto militante e ideológico do período, marcado pela hegemonia do Cinema Novo, impede

\footnotetext{
${ }^{4}$ De forma complementar, podemos mencionar ainda o exemplo da escola canadense. Na sua vertente anglófona, despontaria o chamado candid-eye que, em muitos aspectos, assemelha-se à tradição norte-americana aqui mencionada. Já na província do Québec, de influência francesa, aflora outro núcleo, com destaque para o protagonismo de Pierre Perrault e Michel Brault. De forma sucinta, a produção deste último grupo pode ser enquadrada como um cinema de celebração identitária; portanto, em sintonia com a "Revolução Tranquila", movimento social de reivindicação política, de afirmação cultural e de secularização que aflora no Québec dos anos de 1960, após décadas de alijamento político desta província pela maioria inglesa do país (GAULTHIER, 2011).
} 
nossos realizadores de minimizar sua voz e autoridade no filme; em suma, de aderir integralmente à novidade. Em outros termos, a base tecnológica e a estilística do documentário moderno são gradualmente incorporadas à prática cinematográfica brasileira, mas sua premissa ética recua ante o anseio dos diretores de ainda usar sua arte como púlpito para educar o espectador (RAMOS, 2008).

Para alguns pesquisadores, todavia, o filme que verdadeiramente inaugura entre nós um uso generoso das premissas do direto, comportando uma maior abertura à alteridade e às ambiguidades do "real", seria Cabra marcado para morrer (Eduardo Coutinho, 1984) ${ }^{5}$. Como toda eleição que aponta balizas inaugurais ou obras canônicas, creio que esta escolha solicita ponderações. Seu risco maior é o de eclipsar outros títulos que, nos anos de maturação e transição do documentário brasileiro, contribuíram para alavancar este domínio, antecipando práticas inéditas entre nós e promovendo outro engajamento do espectador na tomada. Assim, sem minimizar os méritos de Cabra marcado, meu objetivo no presente texto é destacar o pioneirismo de três outros trabalhos anteriores neste ciclo de mudanças: os curtas Di-Glauber (Glauber Rocha, 1977), Greve! (João Batista de Andrade, 1979) e Mato eles? (Sérgio Bianchi, 1982) .

Creio ser relevante ampliar aqui a justificativa para a escolha desta tríade. Ao lançar Cineastas e Imagens do Povo (originalmente publicado em 1985), obra cujos resultados são bem conhecidos entre os investigadores do audiovisual, Bernardet já nos prestigiara com um amplo inventário das produções nacionais que vão de 1963 a 1983. Ao investigar como a alteridade aflora nos

\footnotetext{
${ }^{5}$ Ver Bernardet (2003) e Da-Rin (2004), entre outros trabalhos.

${ }^{6}$ A rigor, se nos amparássemos aqui nas categorias definidas por Nichols (2005) e Renov (2004), poderíamos avançar em nossas considerações e afirmar que tais filmes, embora situados no ciclo do documentário moderno, já portam características do documentário contemporâneo. Pensemos, por exemplo, no viés autobiográfico do Cabra marcado (um exercício fílmico também em $1^{\mathrm{a}}$ pessoa) e na conduta performática de Glauber, no seu explosivo curta. Todavia, para efeito didático, restringir-me-ei ao contexto de sedimentação da nossa modernidade documentária, marcado pelo emprego generoso do direto e pela afirmação das práticas reflexivas em oposição a qualquer pretensão especular.
} 
documentários brasileiros que primeiro empregaram o registro síncrono, Bernardet depara-se com títulos onde a premissa ética do direto quase sempre é negligenciada e o outro abordado converte-se em amostragem para ilustrar uma tese prévia anterior ao filme (eis a gênese de sua precisa categoria documentário sociológico). Em sua análise, ressalto, o ensaísta depara-se com obras de transição, que suscitam um olhar mais positivo para a prática documentária no Brasil e um desejo de reinvenção dos cineastas, ainda que poucos exemplares, é fato, ecoem a magnitude do direto. Tal fulgurância será identificada precisamente no antológico filme de Coutinho; tanto que, na nova edição do livro, publicada em 2003, Bernardet optou por incluir, no apêndice, o ensaio Vitória sobre a lata de lixo da história, ilustrativo de seu apreço e reconhecimento da singularidade de Cabra marcado neste ciclo.

Da tríade que mencionei, reitero, Greve! é contemplado por Bernardet, embora sua leitura privilegie outro foco, mas os dois outros títulos, que considero obras seminais do nosso documentário, permanecem ausentes do livro, carecendo de reconsideração. Em minha avaliação, tais filmes antecipam e inauguram muitos dos procedimentos que seriam aplicados com vigor no documentário de Coutinho - um pioneirismo que solicita reconhecimento e pormenorização. Destaco, porém, que a lista de trabalhos pioneiros nesta fase de transição, aqui não abordada em virtude da limitação física do artigo, comportaria ainda outros títulos, a exemplo de Caso Norte (1973) e Wilsinho Galiléia (1979), de João Batista de Andrade, e Bethânia bem de perto (1966), da dupla Bressane e Escorel, produções igualmente negligenciadas por Bernardet, embora suas realizações antecedessem o lançamento de Cineastas e Imagens do Povo. Creio que a inclusão de tais filmes nesta obra, hoje clássica, talvez contribuísse na reformulação de algumas hipóteses alavancadas pelo ensaísta, além de minimizar o pioneirismo de Cabra marcado - o que não implica em desvalorizá-lo. Assim, neste artigo, penso que uma forma de me esquivar parcialmente de suas colocações seria me voltar para as produções relevantes deste ciclo não privilegiadas por ele. Como entender a exclusão destes títulos do seu livro é tema para outra investigação, acredito. 
Ressalto que não é ambição deste artigo propor retificações ao estudo de Bernardet; penso em estabelecer certa complementaridade, em alargar o território por ele garimpado. Além disso, considerando-se o limite físico da publicação, quero ressaltar o ideal de incompletude do presente texto explicitado em seu próprio título: o que proponho são notas, apontamentos, considerações sobre este período de transformação e reformulação da prática documentária no Brasil e sobre três obras relevantes, a meu ver eclipsadas pela fulgurância de Cabra marcado. Ressalto o sentido de incompletude porque tenho convicção de que alguns destes filmes, como Di-Glauber e o próprio Cabra marcado, demandariam bem mais do que um artigo para serem devidamente esmiuçados.

Concluída esta introdução onde recapitulamos o contexto de florescimento do cinema direto e alguns de seus preceitos centrais, cabe delinear o percurso seguinte do artigo. Na nova etapa, iniciaremos o empreendimento analítico com uma breve releitura de Cabra marcado, vislumbrando suas inovações estéticas e importância histórica, precisamente alguns dos elementos que lhe notabilizaram no cinema brasileiro. Em seguida, de forma retrospectiva, lançamo-nos a uma investigação atenta dos títulos de Rocha, Batista e Bianchi, identificando suas singularidades e os procedimentos pioneiros postos em prática por seus realizadores.

\section{Cabra marcado para morrer}

A complexidade desta obra pode ser atestada pela montagem eficiente, que consegue ordenar e organizar um grande número de registros imagéticos e sonoros heterogêneos, com notável descontinuidade espaço-temporal entre eles. No filme, despontam imagens documentais dos anos de 1960, trechos do Cabra marcado original ${ }^{7}$, fotografias e recortes de jornais da época, depoimentos e

\footnotetext{
${ }^{7}$ Projeto iniciado no âmbito do Centro Popular de Cultura da UNE (CPC-UNE), focado na emergência das ligas camponesas e na figura exemplar de João Pedro Teixeira, líder político da Liga de Sapé, num
} 
entrevistas com os antigos atores, múltiplas vozes narrativas, tomadas da equipe durante a realização do segundo projeto e sequências investigativas sobre o paradeiro da família de João Pedro e Elizabeth Teixeira. Num primeiro momento, ao analisarmos a pluralidade de fontes e o encadeamento narrativo do filme, temos a impressão de que a obra parece se amparar numa articulação descontínua e até dispersiva. Como sugere Gervaiseau (2000), a sucessão de fragmentos heterogêneos parece reenviar o espectador a uma multiplicidade de lugares, tempos, ações e materiais, sem estabelecer conexões evidentes. Esta primeira leitura, todavia, não deve eclipsar a vitalidade do filme e nos impedir de perceber sua rica tapeçaria. Longe de ser um demérito, a disposição narrativa do Cabra marcado e o delicado trabalho de montagem - que concilia temporalidades e espacialidades diferentes, registros estilísticos díspares e inúmeras vozes a falar - revelam um esforço para promover uma convergência entre forma e conteúdo na obra. Na cinematografia de Coutinho, o Cabra marcado é precisamente a sua primeira obra a apostar na força do ato rememorativo e na eloquência dos sujeitos em cena (o interesse pela oralidade é referendado não apenas pela partilha da voz e a confiança na fala do outro a recapitular sua trajetória, mas também pela apreensão dos vestígios de uma cultura oral entre nós - de suas marcas de expressão). Deduzimos, pois, que a forma definida pela montagem/edição é fragmentada e lacunar porque a memória, o grande tema do filme, também o é. Assim, em vez de vacuidade narrativa, teríamos, então, uma sintonia entre a moldura narrativa e o conteúdo abordado.

Em contraposição à tendência dominante no documentário brasileiro à época, a chamada abordagem "sociológica", que convertia o filme na ilustração de uma tese amparada em generalizações e relações de causalidade (BERNARDET, 2003), em Cabra marcado predomina o respeito pela ambiguidade/complexidade dos

exercício de reencenação de sua trajetória e assassinato. Sua realização sofre interdição militar em 1964, com apenas $40 \%$ das filmagens concluídas. Em 1981, Coutinho retoma o projeto, agora reformulado como um documentário sobre o filme inacabado e o paradeiro dos camponeses que participaram desta experiência. 
temas abordados, sem a imposição de leituras preferenciais. Deste modo, a obra pode ser interpretada por múltiplos olhares. Cabra marcado é, respectivamente, o filme do golpe e da abertura política - as cicatrizes destes momentos históricos despontam nos recortes de jornais inseridos, na arbitrariedade da ação militar, na impunidade dos crimes no campo e no esfacelamento de muitas famílias jamais recompostas. O documentário é também um registro reflexivo, que mescla um exercício de intertextualidade e metalinguagem sobre uma obra inacabada e interrompida bruscamente, e as consequências desta interdição na trajetória dos principais envolvidos. Por outro lado, ao instigar a memória dos camponeses protagonistas das filmagens originais e ponderar sobre o subsequente destino de suas vidas, a obra converte-se em rico registro memorialístico sem pretensões de fidelidade histórica ou de propor qualquer conclusão esquemática. Por fim, Cabra marcado é também um exercício revisionista e crítico do modelo de cinema político defendido por certa intelectualidade dos anos de 1960.

$\mathrm{E}$, diferentemente do que verificamos em grande parte dos documentários brasileiros das décadas anteriores, onde havia uma nítida separação entre 0 sujeito cineasta e o objeto por ele abordado, postura defensiva que evitava contaminações, neste título Coutinho é um personagem relevante (lembremos que também sua história de vida foi afetada pela interrupção do projeto original). Portanto, a subjetividade/olhar do diretor manifesta-se enfaticamente ao longo do filme, como atestam os muitos trechos narrativos em primeira pessoa e sua recorrente presença física nas imagens. Em resumo, Cabra marcado não se confunde com um registro autobiográfico, mas sua força deriva igualmente deste passado comum compartilhado por cineasta e camponeses; e obstruído por um episódio dramático (embora a tragédia tenha implicações diferentes para cada facção envolvida neste processo). Lembro ainda que, embora não abandone por completo a estilística clássica, tendo em vista sua natureza investigativa, Cabra marcado faz um uso competente e austero da técnica do direto, apostando no improviso e na interação não premeditada (LINS, 2004). Por fim, o filme também inova ao eleger a reelaboração de memória subterrâneas (POLLAK, 1989), 
supostamente confinadas ao silêncio, como dispositivo e ao valorizar a interlocução, transformando a entrevista em conversa, plena de diálogos, mas também de vazios e silêncios, ricos em sua eficácia comunicativa ${ }^{8}$.

A ousadia estilística e a relevância política do Cabra marcado, claro, implicaram num imediato reconhecimento da crítica brasileira e internacional. No entanto, parece-me que sua consagração terminou por encobrir os méritos de outras obras que, realizadas antes, colaboraram igualmente para alavancar a tradição documentária brasileira. Embora sem a mesma projeção do Cabra marcado, tais títulos contribuíram para sedimentar o documentário moderno brasileiro. E, mesmo quando se utilizam de base técnica pré-moderna e de uma narração em off (típicas do padrão clássico), caso de Di-Glauber, inovam na abordagem, no processo de edição/montagem, na incorporação da reflexividade e na autocrítica às pretensões totalizantes do documentário. Além disso, Di-Glauber e Mato eles? partilham um caráter experimental - são filmes pouco preocupados em narrar ou em reforçar as convenções do domínio não-ficcional, preferindo apostar na desconstrução e no gesto provocador. Avancemos, pois, na identificação do pioneirismo de três títulos relevantes desta fase, obras cujas singularidades antecipam alguns dos procedimentos empregados em Cabra marcado ou apontam para práticas pouco usuais entre nossos documentaristas. O paralelo entre as obras (virtudes estilísticas e tendências precursoras), reitero, será mais implícito do que por meio de comparações diretas.

\section{Di-Glauber}

Ao ouvir no rádio a notícia sobre a morte do amigo e pintor Di Cavalcanti, em outubro de 1976, Glauber reuniu alguns rolos de filme, uma câmera emprestada e

\footnotetext{
${ }^{8}$ Outro mérito evidente do Cabra marcado, poucas vezes ressaltado, é ter familiarizado o espectador da época com as produções documentais em longa-metragem. Lembremo-nos que boa parte das obras de não ficção produzidas no Brasil, nas décadas anteriores, possuía uma duração inferior a 60 minutos.
} 
seguiu com o fotógrafo Mário Carneiro para registrar o velório do artista, sob protesto dos familiares presentes. Com pouco mais de 15 minutos de duração, o curta, cuja exibição permanece vetada por solicitação dos herdeiros do pintor, é polêmico já a partir da indefinição de seu título9 ${ }^{9}$ Obra que permite múltiplas abordagens, Di-Glauber não é um trabalho descritivo e didático sobre o velório/sepultamento de uma celebridade das artes brasileiras, tampouco uma cinebiografia, formato hoje tão em voga. Filmado em quatro locações diferentes no Museu de Arte Moderna (RJ), no Cemitério São João Batista (RJ), numa exposição de quadros de Di e no apartamento do cineasta -, a produção subverte o caráter solene dos ritos funerários (a melancolia do luto é substituída pela carnavalização da morte e por uma subsequente apologia da vida), apresentandonos um pintor de ímpeto e talento exuberantes. Tudo isso catalisado pela personalidade inquieta e dionisíaca do diretor.

A reflexividade e a prática da metalinguagem também são recorrentes no curta, com Glauber frequentemente em cena (presença física ou narrativa), a comentar/ler, em tom radiofônico, irônico e distante da formalidade da voz over, as matérias jornalísticas do período que noticiavam a realização do filme e a controvérsia com os familiares. Em outro momento, Glauber modula novamente a voz para declamar um poema de Vinícius de Moraes consagrado ao pintor. Mais à frente, em passagem eminentemente memorialística, Glauber relembra seus encontros com Di Cavalcanti - aqui, o tom da fala é cordial, afetuoso sem afetação, um misto de depoimento e confissão. E, quando se insere fisicamente no documentário, sua presença é performática, a exemplo do plano em que parece liderar o cortejo funerário. Nesta cena, sua conduta é a de quem intervém para forjar a situação a ser filmada, vencendo resistências; e, embora não tenha registro direto, o off, não raro, simula o que poderia ser a direção enfática de Glauber nestas tomadas, orientando a mise-en-scène, a exemplo das indicações

${ }^{9}$ Di Cavalcanti; Di-Glauber, sugestão do crítico Alex Vianny; ou mesmo Ninguém assistiu ao formidável enterro de sua última quimera; somente a ingratidão, essa pantera, foi sua companheira inseparável, fragmento do poema "Versos Íntimos", de Augusto dos Anjos. 
verbais que acompanham alguns planos do velório ("agora dá uma panorâmica geral e enquadra o caixão no centro. Depois começa a filmar da esquerda para a direita").

Como destaca Mattos, Glauber exerce múltiplos papéis no curta: ele é simultaneamente um narrador transgressor, que não emite relatos formais e, tampouco, emula a indiferença da voz over; é um diretor determinado em seu projeto, ainda que enfrente a resistência familiar; é um personagem cuja presença física tumultua a cena e, claro, um depoente confesso e, não raro, afetuoso (2004, p. 162-164). Talvez, por isso, Alex Vianny tenha Ihe sugerido o título Di-Glauber, destacando assim a centralidade da figura performática do diretor nesta obra. $\mathrm{Na}$ produção, a figura inquieta de Glauber é tão ou mais sedutora do que o pintor falecido; em outras palavras, é sua participação que confere ao curta uma originalidade e ousadia impensáveis à época e, ainda hoje, intrigantes.

O suporte técnico pré-moderno comprovado pela ausência do som direto, então o baluarte do novo documentário ocidental, em momento algum compromete a modernidade do filme ${ }^{10}$. Se, por um lado, em Di-Glauber o som e a imagem não são síncronos, o que é comprovado pela recorrente locução off, por outro, o curta inova ao adotar a reflexividade e a metalinguagem como procedimentos estilísticos: em muitos trechos, o filme refere-se a si e ao processo de sua realização, o que nos permite sugerir que, mais do que um documentário sobre o pintor falecido, Di-Glauber é um filme que problematiza a própria obra em gestação e os entraves que ameaçam o processo criativo. Por outro lado, os comentários frequentes de Glauber sobre a execução do curta, aliados à câmera sempre nervosa e à montagem frenética, não nos permitem enveredar por

\footnotetext{
${ }^{10}$ Percebemos aqui que o recorte clássico versus moderno, no documentário, não pode se amparar num debate puramente tecnológico (sobre o dispositivo de registro empregado pelo cineasta). Bem mais relevante é a conduta ética e a vontade estética do realizador - o seu desejo de subverter as fronteiras anteriormente estabelecidas, independente de dispor ou não do melhor artefato de registro. A observação é válida para avaliarmos outro título ainda mais impactante, sobretudo porque produzido antes do boom do cinema direto: trata-se do filme Eu, um negro (Jean Rouch, 1958), obra igualmente pré-moderna em sua base técnica, mas moderníssima em seus resultados estéticos e políticos.
} 
quaisquer ilusionismos - longe de manifestar pretensões objetivas, testemunhamos uma obra passional, visceral, conectada à subjetividade de seu realizador.

\section{Greve!}

No contexto das grandes greves do ABC paulista, em fins de 1970, podemos identificar na obra de cineastas como Renato Tapajós, Leon Hirszman e João Batista de Andrade, certa adesão cinematográfica à causa metalúrgica. Tanto em sua produção documentária - Linha de Montagem (Tapajós, 1982), Greve! e ABC da Greve (Hirszman, 1990) ${ }^{11}$ - como em alguns títulos ficcionais - O Homem que virou Suco (Andrade, 1980) e Eles não usam Black-Tie (Hirszman, 1981). Tendo em vista o silêncio da grande mídia diante dos eventos no $A B C$, ou o caráter oficioso de grande parte da cobertura televisiva, digamos que cada um destes diretores tratou de elaborar a sua versão das greves.

Em linhas gerais, talvez seja possível afirmar que tais filmes, e aqui me refiro aos documentários, nos informariam mais sobre os cineastas e os valores por eles partilhados à época (visões de mundo e vínculos partidários) do que sobre as paralisações em si. Todavia, mais relevante do que a identificação de divergências entre as obras, é o reconhecimento da complementaridade que as conecta: visto que nenhum dos três títulos, pela sua parcialidade, apreende a complexidade das greves do $A B C$, apenas o conjunto deles nos possibilitaria uma compreensão mais sólida do fenômeno, que implicou num renascimento do sindicalismo brasileiro (GRANATO, 2008).

Porém, antes de nos restringirmos ao curta de Andrade, creio ser pertinente delinearmos algumas particularidades de sua prática documentária, em contraste, por exemplo, com a de Tapajós. Ex-militante do partido comunista, Andrade notabiliza-se no final dos anos de 1960 pelo teor político de sua cinematografia e

\footnotetext{
${ }^{11}$ Filmado no período de eclosão das grandes greves, o filme de Hirszman só foi finalizado em 1990.
} 
por sua estilística da intervenção (BERNARDET, 2003, p. 186 a 292 e p. 259 a 262). Seus documentários da época destacam-se pela câmera participativa, enfática e distante da postura meramente observativa, e pelo papel dramático vivenciado pelo cineasta na tomada. Em outras palavras, o diretor também assume a condição de personagem, intervindo na cena, produzindo fissuras no real e forjando situações para que os sujeitos por ele abordados (ou provocados) possam se expressar.

Posição diferente, embora não necessariamente oposta, pode ser vislumbrada na obra de Tapajós à época. Ex-integrante da Ala Vermelha (dissidência do PC do B), Tapajós é um cineasta cujo legado artístico se confunde com a resistência política à ditadura e cuja biografia inclui ainda a experiência amarga da tortura nos "anos de chumbo". Antes da realização de Linha de Montagem, Tapajós aproximara-se do Sindicato dos Metalúrgicos de São Bernardo, ministrando oficinas de cinema para alguns de seus dirigentes; posteriormente, em 1977, fora recrutado pelo departamento cultural da entidade para dirigir três curtas protagonizados por operários ${ }^{12}$. Nos títulos deste período, ao contrário do que preconizava Batista, Tapajós investe numa espécie de dramaturgia da transparência, onde a observação se sobrepõe a interação/intervenção e a subjetividade do realizador é minimizada em benefício da voz dos personagens ${ }^{13}$ (não raro, das lideranças sindicais, o que atesta uma inclinação ideológica evidente nestas obras).

Mas avancemos nas considerações sobre o curta de Andrade, sem perder de vista o paralelo com o documentário de Tapajós, já que investi numa breve comparação entre os dois diretores. Em muitos sentidos, Greve! se aproxima de

\footnotetext{
${ }^{12}$ São eles: Acidente de Trabalho (1977); Trabalhadoras Metalúrgicas (1978); e Teatro Operário (1978). Tapajós filmou ainda Greve de Março, documentário sobre as paralisações de 1979, espécie de balão de ensaio para Linha de Montagem.

${ }^{13}$ As categorias intervenção e transparência, associadas a um ou outro destes dois realizadores, são formulações de Bernardet, (2003, p. 186 a 202). Ambas, de certo modo, podem ser entendidas como variações do cinema-verdade francês e do cinema direto norte-americano.
} 
Linha de Montagem. O foco central é o mesmo e grande parte das locações, inevitavelmente, repete-se: o estádio da Vila Euclides, o Paço Municipal, a Igreja Matriz de São Bernardo, o sindicato, a portaria das grandes montadoras onde são organizados os piquetes... De forma previsível, algumas tomadas e eventos relevantes são comuns à articulação narrativa dos dois filmes. Todavia, entre eles, também há diferenças evidentes, que ratificam o perfil delineado para cada cineasta.

Ao contrário do filme de Tapajós, o documentário de Batista não manifesta adesão irrestrita aos trabalhadores (podemos falar, talvez, de uma adesão crítica), tampouco se limita a reiterar o ponto de vista da entidade sindical. Em Greve!, o laço fraternal se dilui em benefício de uma postura investigativa que se insere no epicentro dos acontecimentos para avaliar suas tensões, contradições e ambiguidades (em outros termos, o direto não é usado somente para promover encontros e convergências, mas também para suscitar polarizações). Principais protagonistas, os operários, e não os dirigentes sindicais, são convocados a falar e a ponderar sobre as paralisações; neste exercício, suas falas, não raro, atestam divergências. E, diferentemente do que vislumbramos em Linha de Montagem, no curta os trabalhadores não são abordados apenas nos espaços públicos que abrigam as assembléias. Muitas vezes, são flagrados no ambiente doméstico/cotidiano, situação que, por um lado, arrefece o ideal de força ou comunhão da categoria (evidente nas cenas que priorizam a coletividade), mas, por outro, tendo em vista o foco na intimidade, possibilita-nos um maior acesso às suas aflições e fragilidades.

Produção menos esmerada que Linha de Montagem (e sem financiamento sindical), o curta de Andrade não prima pelo acabamento: Greve! concilia múltiplos dispositivos de registro, bem como tomadas a cores com outras em preto-e-branco ou de tonalidade sépia. Em termos de abrangência, o documentário também restringe seu foco à paralisação de 1979. Porém, a conduta do realizador é menos parcial: no filme, Andrade não hesita em questionar a adesão integral à greve, vislumbrando brechas na suposta unificação 
alardeada pelos metalúrgicos. Testemunhamos, é fato, momentos de euforia e de reivindicação, mas o curta também apresenta-nos instantes de tensão e de pulverização da categoria, como atestam os planos que registram a intensificação policial nas ruas, o fechamento e intervenção do sindicato, a ocupação e o esvaziamento do estádio da Vila Euclides. Em outra sequência, a câmera se desloca por bairros periféricos de São Bernardo, com ruas enlameadas e apinhadas de casebres, majoritariamente ocupados por metalúrgicos. Aqui, com sutileza, Batista inicia a desconstrução de uma velha bravata - a de que o operariado do $\mathrm{ABC}$ constituiria uma espécie de minoria privilegiada no País. Este processo de pauperização, é importante ressaltar, encontra-se alijado do filme de Tapajós, que prefere investir na dignidade da categoria.

O contraste entre os dois documentários também evidencia-se na sequência final, que nos apresenta Lula discursando para a multidão. Esta é sua primeira inserção direta no curta; mas a equipe de Andrade não parece interessada no sindicalista, preferindo deslocar-se pela multidão irmanada. Emblemático, o plano final de Greve! exibe a massa operária de mãos dadas e braços erguidos, destacando sua unidade, mas deslocando o sindicalista do quadro. É como se o diretor nos advertisse: o culto ao líder não é prioridade; a força do movimento reside na categoria e não na entidade que Ihes representa. Enfim, no curta de Andrade o líder sindicalista nunca é filmado em tomadas próximas, que reforcem seu carisma. Quando o observamos, está sempre à distância e ladeado por outros companheiros. Em outras palavras, fazendo um uso austero do direto, em Greve! Andrade dialoga com os metalúrgicos sem se submeter ao movimento sindical; tampouco sem abdicar de seu método característico - intervenção, provocação, ativação de fissuras no real.

\section{Mato eles?}

Não apenas pela figura célebre e incendiária de Glauber Rocha, mas também pelos problemas que envolveram sua realização e interdição, Di-Glauber é uma 
produção que desfruta de relativa popularidade entre os cinéfilos, se o compararmos ao quase anonimato em que se encontram Greve! e Mato eles? É precisamente devido a este desequilíbrio na balança da popularidade que optei por direcionar um olhar um pouco mais extenso a estes dois últimos títulos.

Em linhas gerais, e ao contrário do que se verifica com Di-Glauber, não é difícil traçar uma sinopse de Mato eles? Realizado em 1982, ainda sob o regime militar, o filme aborda os dilemas vivenciados por três etnias indígenas (Kaingangs, Guaranis e Xetás), instaladas na reserva de Mangueirinha, no Paraná, administrada pela Fundação Nacional do Índio (Funai). Todavia, apesar da demarcação territorial assegurada, dois problemas comprometiam a sobrevivência das comunidades: de forma suspeita, a parte mais rica da reserva fora comprada por uma madeireira, negociata que, à ocasião, se convertera em lento processo litigioso sobre a posse definitiva da área; por outro lado, no território ocupado pelos índios, a Funai instalara uma serraria que, sob a alegação de promover o êxito econômico da reserva, ameaçava devastar a mata residual da região. Em outras palavras, os índios estavam sendo gradualmente exterminados com o consentimento daqueles que, formalmente, deveriam protegê-los.

No entanto, esta matéria-prima de elevado teor político, que poderia resultar num filme militante e excessivamente didático (certamente relevante, mas sem inovações formais), encontra na verve ácida de Bianchi outras vias de desenvolvimento e maturação. Sem dúvida, Mato eles? promove a denúncia esperada, nos sensibiliza para a sina trágica das três etnias, mas também instiga e desnaturaliza o olhar do espectador ao adotar como estratégia a desconstrução do documentário tradicional. Como sugere Oliveira, em análise deste filme, "a rebeldia formal radicaliza o conteúdo político, desmascarando com risível ironia a fragilidade conceitual de suas pretensões didático-pedagógicas e a ilusão de imparcialidade do discurso" (2006, p. 36).

Portanto, no curta, Bianchi concilia o exercício da denúncia com um formato provocativo que contrasta imagens e sons, amplifica sentidos e promove ambiguidades, sem perder de vista a autocrítica (o papel do documentário é 
sempre revisado e censurado, bem como o dilema do artista cineasta - sua crise de consciência enquanto parte potencialmente beneficiária do sistema que se propõe a criticar). A reflexividade, por tabela, é prática recorrente no filme, atestada pela aparição enfática dos equipamentos e do diretor, seja conduzindo a mise-en-scène ou ressignificando a fala dos entrevistados. A presença física de Bianchi ou de sua voz grave intervém de forma irônica e crítica no decorrer do filme, articulando a pluralidade dos discursos envolvidos e abusando da montagem como recurso manipulativo - é por meio da montagem (seca e incisiva) que ele se manifesta, questiona, estimula uma fala ou implode os argumentos de um entrevistado suspeito ${ }^{14}$. Diante da impossibilidade, por exemplo, de reunir facções adversárias em um mesmo plano, ele utiliza a montagem para promover acareações artificiais, fomentar desconfianças, minimizar a sobriedade de alguns personagens e, ao mesmo tempo, conferir ênfase a fala de outros.

Assim, em Mato eles?, pouca coisa pode ser compreendida de forma literal, sem suscitar desconfiança, uma vez que o uso sistemático da ironia conduz a narrativa e mobiliza a sensibilidade do espectador, produzindo efeitos dramáticos e cômicos, acirrando contrastes e conflitos, promovendo contrapontos e amplificando a complexidade das imagens. A ambiguidade materializa-se, por exemplo, na banda sonora que tripudia de algumas imagens (narrativas que desautorizam ou nos estimulam a desacreditar no que vemos); nos planos em que desmistificam o que é dito; e na intercalação de tomadas documentais e ficcionais - no curta, Bianchi com frequência emprega atores cujas falas confundem ainda mais a percepção do espectador menos familiarizado com a miscelânea de procedimentos. O emprego da ironia, claro, não poupa o formato documental, cuja estilística clássica (o olhar autoritário e sapiente sobre o outro) é sempre

\footnotetext{
${ }^{14}$ Como observa Robert Stam, neste filme, "Bianchi ridiculariza tanto o discurso oficial sobre os índios quanto a boa consciência burguesa evidente nos tradicionais documentários de denúncia” (2013, p. 33 e 34, tradução minha). A desconstrução, atesta o autor, é mais incisiva: Mato eles? zombaria da tradicional exaltação romântica-indianista do nativo ao revelar que os bravos guerreiros dos poetas do século XIX estão agora presos no século XX, em um sombrio ciclo de impotência e empobrecimento.
} 
questionada.

Exemplo desta crítica desponta no quadro "Sérgio Bianchi apresenta o último Xetá", uma espécie de paródia dos filmes etnográficos tradicionais, que recorre a imagens de arquivo (antigas expedições tuteladas pela UFPR ou outra instituição?) e desautoriza a suposta objetividade destas produções. Numa das passagens desta sequência, o diretor é visto em cena orientando enfaticamente o enquadramento de um indígena - a manobra do cineasta sugere ao espectador que, mesmo nos títulos com aspiração científica (caso dos filmes etnográficos), a imparcialidade é uma quimera. No limite, prevaleceriam a natureza manipuladora e os artifícios de mise-en-scène evidentes em qualquer obra fílmica. A inserção ambígua de Bianchi (presença física e/ou sonora) não raro nos convida a duvidar do seu próprio trabalho, compondo uma espécie de autocrítica (afinal, que legitimidade possui o cineasta branco para falar em nome dos indígenas?). Autocrítica que será reforçada nos planos finais do filme, nos quais acompanhamos um índio abordar o cineasta com desconfiança sobre a finalidade do curta e o objetivo de suas perguntas, ciente de que também o diretor é mais um a lucrar com a tragédia de seus pares. Seguindo o estilo "cortar na carne", para atingir um resultado mais eficiente, Bianchi não exclui o questionamento na edição - ou seja, não poupa a si e nem ao filme. Como indica Oliveira, o ironista se insere no próprio sistema crítico que põe em movimento, aceitando a condição de alvo a ser implodido (2006, p. 71 e 72 ). Todavia, é preciso destacar que a estrutura ambígua do filme não nos impede de perceber sua contundência política: a ingerência burocrática do Estado a serviço de interesses escusos e a marginalização social das comunidades indígenas são igualmente ressaltadas ${ }^{15}$.

\footnotetext{
${ }^{15}$ Algumas informações extra-fílmicas podem nos auxiliar a entender a beligerância do curta de Bianchi. Amparo-me nos relatos de Oliveira (2006). O filme teria sido financiado pela Secretaria de Cultura do Paraná, após sucessivas investidas de Bianchi que desejava levantar verba para novos projetos. O dinheiro em questão fora concedido, mas deveria ser aplicado em um filme sobre a reserva de Mangueirinha. Bianchi concordou e obteve carta branca para entrar na reserva e filmar o que bem entendesse (inclusive as áreas consideradas focos de instabilidades). Mas, ao contrário do que
} 
Dois outros exemplos atestam a conduta do diretor em seu emprego da ironia. Entre uma sequência e outra do curta, e geralmente após uma fala nada empática, Bianchi propõe questionários ao espectador, no formato de cartelas, que nos estimulam a desconfiar do entrevistado, da locução ou mesmo das intenções do filme. A ênfase nas perguntas, sempre provocativas e nunca acompanhadas da apresentação explícita das respostas, leva-nos a sugerir que Mato eles? é um filme muito mais interessado em estimular dúvidas do que em propor soluções. Por outro lado, diferentemente de Coutinho, que mantém uma postura austera e receptiva diante do outro abordado, Bianchi não se isenta de julgar o entrevistado. É o que nos revela o exemplo seguinte: diante da postura defensiva de um dos dirigentes da Funai, que insiste na viabilidade e legalidade da madeireira, o diretor utiliza-se da edição para inserir grandes cifras na tela e o off de uma velha caixa registradora com seu "tilintar" característico - tal sonoridade nos leva a associar o burocrata, em sua ganância evidente, com uma ave de rapina ${ }^{16}$.

A importância de Bianchi neste filme (apenas sua personalidade poderia conferir a Mato eles? um teor incendiário e beligerante) nos leva a pensar em alguns documentários, a exemplo dos já citados Di-Glauber e Cabra marcado, onde a presença enfática do diretor é peça-chave para o êxito da obra; em outras palavras, são filmes que encontram sua melhor expressão em virtude da relação umbilical com seus realizadores. Impossível, pois, imaginar a ousadia de DiGlauber nas mãos de outro diretor ou testemunhar as transformações de personalidade vivenciadas por Elizabeth Teixeira, caso a viúva de João Pedro tivesse à sua frente outro interlocutor que não Coutinho. Idêntica leitura poderia ser aplicada a Santiago (João Moreira Salles, 2007), uma vez que as reflexões

esperava o governo estadual, o resultado, como hoje o conhecemos, está longe de ser um filme institucional, voltado à divulgação dos progressos obtidos pelo regime militar na área social e na proteção aos nativos. Como era previsível, Mato eles? enfrentou entraves por parte de censores. Após lentas negociações, porém, a obra acabou sendo liberada e exibida em circuitos alternativos.

${ }^{16}$ O uso sistemático da ironia, porém, também pode implicar em alguns riscos: afinal, nem todos estão preparados para entender suas sutilezas, o que inevitavelmente pode estimular leituras imprevistas. 
induzidas pelo copião do filme, sobretudo aquelas que possuem dimensão memorialística e afetiva, somente poderiam despontar das reminiscências de Salles.

Finalizo esta análise sobre três títulos importantes, e por vezes esquecidos, de nossa cinematografia com rápidas considerações. Se Di-Glauber é obra pioneira na prática da metalinguagem e da reflexividade, Mato eles? aprofunda o teor reflexivo e é implacável na desconstrução das supostas virtudes do documentário clássico (a rigor, insiste o filme, tudo deve ser encarado com desconfiança). Por outro lado, ao mesclar ostensivamente elementos da ficção e do documentário, Mato eles? parece antecipar, entre nós, a discussão sobre as possíveis fronteiras e convergências entre os dois domínios, implodindo qualquer rigidez conceitual. Se hoje esta questão centraliza boa parte dos volumes teóricos e instiga realizadores de múltiplas tendências, é sempre bom lembrar que, no Brasil de 1982, em lento processo de redemocratização, tais procedimentos não eram rotina. Menos ousado do ponto de vista formal, Greve! se sobressai pelo uso sensato das potências do direto, delineando-nos, através da intervenção e do agenciamento pontual do diretor, um painel menos parcial e mais complexo das tensões em jogo no contexto das grandes paralisações do ABC. O filme, ressalto, não desconstrói a unidade da categoria metalúrgica; sua virtude é materializar os impasses e dúvidas inevitáveis em qualquer grande evento político.

À sua maneira, cada um destes títulos colocou em prática procedimentos inovadores, que implodiram o padrão clássico e anunciavam a plena modernidade (quando não a contemporaneidade) do nosso documentário; Cabra marcado, em certa medida, mobiliza parte deste arsenal com grande êxito, o que é atestado por sua fortuna crítica. Neste artigo, como já ressaltei, não buscamos minimizar os méritos do filme de Coutinho, mas destacar que, neste ciclo de transformação e afirmação, sua obra magistral teve antecedentes qualificados, filmes cujo pioneirismo carecia de uma justa mensuração. 


\section{Referências Bibliográficas}

BERNARDET, Jean Claude. Cineastas e imagens do povo. São Paulo: Companhia das Letras, 2003.

BARNOUW, Erik. Documentary - a history of the non-fiction film. Nova York: Oxford University Press, 1993.

COMOLLI, Jean-Louis. "O desvio pelo direto". In: Catálogo do 14. Festival do Filme Documentário e Etnográfico - Fórum de Antropologia, Cinema e Vídeo (Forumdoc.BH), 2010, p. 294 a 317. Publicação e realização da Associação Filmes de Quintal, em parceria com a Faculdade de Filosofia e Ciências Humanas (Fafich) da Universidade Federal de Minas Gerais (UFMG). Disponível em <http://www.forumdoc.org.br/2010/catalogo2010.pdf> Consultado em 19-042014. Estes ensaios foram originalmente publicados em Cahiers du Cinéma, n. 209, fevereiro, e n. 211, abril, de 1969, com o título Le Detour par le Dirèct.

DA-RIN, Sílvio. Espelho partido - tradição e transformação do documentário. Rio de Janeiro: Azougue Editorial, 2004.

DELEUZE, Gilles. A imagem-tempo: Cinema 2. $2^{\mathrm{a}}$ edição. São Paulo: Brasiliense, 2009.

GAUTHIER, Guy. O documentário: um outro cinema. Campinas: Papirus, 2011.

GERVAISEAU, Henri Arraes. O Abrigo do Tempo. Tese de doutorado defendida na Escola de Comunicação (ECO) da UFRJ, sob orientação do prof. André Parente. Rio de Janeiro, 2000.

MARCORELLES, Louis. (org.). Living cinema. London: Cox \& Wyman, 1973.

JACOBS, Lewis. The documentary tradition. Norton \& Company, Londres, 1979.

LINS, Consuelo. O documentário de Eduardo Coutinho. Rio de Janeiro: Jorge Zahar, 2004.

MATTOS, Tetê. "A imaginação cinematográfica em Di-Glauber". In: TEIXEIRA, Francisco Elinaldo. (org.). Documentário no Brasil - Tradição e Transformação. São Paulo: Summus Editorial, 2004.

NICHOLS, Bill. Introdução ao documentário. Campinas, Papirus, 2005.

OLIVEIRA, Nezi. O cinema autoral de Sérgio Bianchi: Uma visão crítica e irônica da realidade brasileira. Dissertação de mestrado defendida na Escola de 
Comunicações e Artes da USP, sob orientação do professor Henri Gervaiseau. São Paulo, 2006.

POLLAK, Michael. "Memória, esquecimento, silêncio". In: Estudos históricos. Rio de Janeiro. vol. 2, $\mathrm{n}^{\circ} 3$, pp. 3-15, 1989. Disponível em: $<$ http://bibliotecadigital.fgv.br/ojs/index.php/reh/article/view/2278/1417>. [acesso em 10 de dezembro de 2013]

RAMOS, Fernão Pessoa. Mas afinal... O que é mesmo documentário? São Paulo: Editora Senac, 2008.

RENOV, Michael. The subject of documentary. Minneapolis: University of Minnesota Press, 2004.

ROTHMAN, William. Documentary Film Classics. Cambridge University Press, Nova York, 1997.

SILVA, Maria Carolina Granato da. O cinema na greve e a greve no cinema: Memórias dos metalúrgicos do ABC. Tese de Doutorado defendida no Programa de Pós-Graduação em História da Universidade Federal Fluminense, sob orientação da profa. Laura Antunes Maciel. Niterói, 2008.

STAM, Robert. "Hybrid variations on a documentary theme". In: Rebeca - Revista Brasileira de Estudos de Cinema e Audiovisual. Publicação da Sociedade Brasileira de Estudos de Cinema e Audiovisual (Socine). Ano 2, n. 4, julho-dezembro de 2013, pp. 15-36. ISSN: 2316-9230. Disponível em <http://www.socine.org.br/Rebeca/pdf/rebeca_4_00.pdf> [acesso em 18 de abril de 2014] 